\title{
PENGGUNAAN MODEL TGT DENGAN MEDIA BARCODE SCANNER UNTUK MENINGKATKAN MOTIVASI SISWA
}

\author{
Subadi \\ SMA Negeri 1 Matauli Pandan \\ Email: subadijbg@gmail.com
}

(Diterima: 20 Oktober 2020; Disetujui: 12 Desember 2020; Publikasi: 31 Desember 2020)

\begin{abstract}
Abstrak
Pembelajaran sejarah di era digital menghadapi tantangan berat, karena persepsi siswa materi pembelajaran dapat dengan mudah dicari di internet. Tujuan penulisan praktik baik ini adalah untuk meningkatkan motivasi, mempergunakan kemajuan teknologi untuk alat bantu pembelajaran, menghindari kegiatan negatif penggunaan android/HP, meningkatkan kreativitas siswa dan pembelajaran yang menyenangkan. Pengumpulan data dilakukan dengan melalui dokumen diantaranya dari daftar nilai hasil belajar siswa, daftar hadir, daftar keaktifan siswa, silabus, RPP, hasil kuesioner/survey motivasi dan minat serta pengamatan secara langsung dan pengalaman praktik-praktik baik. Lokasi praktik baik di SMAN 1 Matauli Pandan melibatkan siswa kelas XII IPA10 berjumlah 24. Dengan mengubah model pembelajaran dengan Team Game Tournament (TGT) menggunakan media HP android dengan aplikasi barcode scanner diperoleh hasil bahwa siswa yang termotivasi dan tertantang belajar sebanyak 21 siswa dari 24 siswa atau sebesar 87,5\%. Siswa yang mengantuk menjadi tidak ada karena semua siswa terlibat dalam permainan menggunakan media barcode scanner. Namun demikian tidak ada satupun siswa yang menyatakan tertarik dan berminat menjadi sejarawan. Hasil belajar dengan media barcode scanner menunjukkan siswa yang tuntas belajar sejarah sebesar $92 \%$ atau 22 siswa, dan yang belum tuntas $8 \%$ atau 2 siswa memperoleh nilai kurang dari 75 . Hasil belajar siswa meningkat dengan rata-rata kelas 84,25 .
\end{abstract}

Kata kunci: Media Barcode Scanner; Motivasi; Team Game Tournament.

\begin{abstract}
Learning history in the digital era faces serious challenges because students can easily search learning materials on the internet. This article discussed the activities of the teacher in the application of Barcode Scanner media, how the Barcode Scanner learning media used, students learning motivation, and students learning outcomes. The aims of writing this good practice were to increase motivation, use advances in technology for learning aids, avoid negative activities using android, increase student creativity and fun learning. Data collection was conducted through examining documents including list of student learning outcomes, attendance lists, student activeness lists, syllabus, lesson plans, results of motivation and interest questionnaires/surveys as well as direct observation and experiences of good practices. The location of good practice at SMAN 1 Matauli Pandan involving 24 students from grade XII IPA 10. By changing the learning model with the Team Game Tournament (TGT) using android smartphone media with a barcode scanner application, students were motivated and challenged to learn, sleepy students were not found there because all students are involved in
\end{abstract}


the game using barcode scanner media. However, none of the students was interested and interested in becoming a historian. Using barcode scanner media, students who have completed learning history by $92 \%$ or 22 students and $8 \%$ or 2 students who have not completed learning scores less than 75. Student learning outcomes increased with an average grade was 84.25 .

Keywords: Media Barcode Scanner; Motivation; TGT

\section{PENDAHULUAN}

Sulit terbantahkan bahwa persepsi siswa terhadap mata pelajaran sejarah itu membosankan dan membuat siswa belajar di kelas sering mengantuk. Bagaimana upaya meningkatkan motivasi belajar siswa dalam pembelajaran sejarah seiring dengan perkembangan ilmu pengetahuan dan teknologi tantangan dan hambatan dalam kegiatan pembelajaran di kelas semakin kompleks? Tatanan kehidupan masyarakat dan lingkungan pergaulan siswa pada masa sekarang tidak bisa lepas dari tuntutan teknologi. Demikian pesatnya perkembangan teknologi informasi, khususnya handphone (HP) membuat setiap orang dari usia balita sampai dengan dewasa bahkan yang sudah usia lanjut semua mengenal dan mempergunakan HP.

Perkembangan teknologi ini tidak bisa dihindari dan bahkan harus diikuti jika tidak ingin tertinggal informasi. Dalam hal ini termasuk kegiatan belajar mengajar di kelas juga mengalami dampak yang hebat. Pola perilaku peserta didik di tingkat Sekolah Menengah Atas (SMA) lebih besar terpengaruh oleh penggunaan HP tersebut, sehingga dalam belajar di kelas siswa menjadi lebih pasif mendengarkan penjelasan materi pembelajaran dari guru. Siswa beranggapan semua informasi tentang materi pembelajaran sudah bisa diperoleh dengan cara berselancar di dunia maya (dengan internet melalui google, yahoo atau media lain). Kondisi ini akan berpengaruh terhadap kegiatan proses belajar mengajar. Oleh sebab itu diperlukan upaya pembaharuan atau inovasi pembelajaran oleh guru agar kegiatan belajar mengajar menjadi menarik dan dapat membawa siswa ikut aktif dalam pembelajaran.

Hasil pengamatan guru dan praktik baik di kelas menunjukkan bahwa proses pembelajaran sejarah di kelas selama ini terjadi cenderung komunikasi satu arah. Informasi hanya datang dari guru kepada siswa, sehingga siswa menjadi kurang terlibat aktif dalam kegiatan pembelajaran seperti berbagi gagasan dan pengalaman, bertanggungjawab terhadap tugas, kemauan menerima pendapat yang lebih baik, bertanya, atau yang lebih buruknya adalah hasil belajar mereka yang tereduksi. Ketidaktepatan penggunaan strategi dan media pembelajaran tersebut menyebabkan rendahnya kemampuan siswa dalam memahami dan menerapkan konsep materi pelajaran yang pada akhirnya siswa memperoleh hasil belajar yang

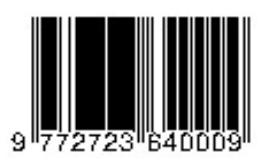


kurang maksimal. Contohnya pada materi Sejarah KD.3.3 tentang Sistem dan struktur politik dan ekonomi masa demokrasi terpimpin, masih terdapat banyak siswa yang belum tuntas perolehan nilainya. Dari nilai kriteria ketuntasan minimal (KKM) 75, jumlah siswa yang telah tuntas tidak mencapai 75\%. Data yang diperoleh adalah sebagai berikut; siswa kurang termotivasi untuk belajar sejarah dan mengantuk sebesar 50\% atau 12 orang, merasa tidak berminat dan tidak tertantang sebesar $83 \%$ atau berjumlah 20, dan sebanyak 9 siswa atau $37 \%$ yang tuntas belajar dan siswa yang tidak tuntas sebanyak 15 siswa atau 63\% dengan rata-rata kelas sebesar 67,46 .

Menurut Kurniari (2006:23), model pembelajaran Team Game Tournament (TGT) merupakan model pembelajaran kooperatif dengan membentuk kelompok-kelompok kecil dalam kelas yang terdiri beberapa siswa yang heterogen, baik dalam hal akademik, jenis kelamin, ras, maupun etnis. Inti dari model ini adalah adanya game atau turnamen akademik. Untuk memastikan apakah semua anggota kelompok telah menguasai materi, maka siswa akan bermain dalam game dan turnamen akademik. Game hanya diikuti oleh perwakilan dari masing-masing kelompok, sedangkan turnamen diikuti oleh semua siswa. Tahapan dalam model pembelajaran TGT menurut Slavin (2001:166-167) adalah tahap presentasi di kelas, tim, game, turnamen dan rekognisi tim. Slavin (2010:163-165) menyatakan pembelajaran TGT merupakan salah satu model pembelajaran yang menggunakan turnamen akademik, kuis-kuis, serta sistem skor kemajuan perwakilan kelompok.

Berdasarkan permasalahan di atas, penulis tertarik untuk memberikan solusi bagaimana upaya meningkatkan motivasi belajar siswa dalam pembelajaran sejarah. Rumusan permasalahan dalam penulisan ini adalah: Bagaimana aktivitas guru dalam penerapan media barcode scanner?, bagaimanakah penggunaan media pembelajaran barcode scanner pada mata pelajaran sejarah, bagaimana motivasi belajar dan hasil belajar siswa? Dengan memperhatikan beberapa kendala dan perkembangan anak didik di era digital maka tujuan penulisan dari penggunaan model pembelajaran TGT dengan media barcode scanner adalah: 1) meningkatkan motivasi dan hasil belajar siswa, 2) mempergunakan kemajuan teknologi untuk alat bantu pembelajaran, 3) menghindari kegiatan yang negatif siswa dalam penggunaan HP/android, 4) meningkatkan kreativitas siswa, dan 5) pembelajaran yang menyenangkan dan efektif. Untuk memperjelas kajian, pengertian-pengertian terkait kata-kata kunci tersebut akan dibahas pada bagian berikut.

Pengertian pembelajaran adalah setiap perubahan perilaku yang relatif permanen, terjadi sebagai hasil pengalaman baik dialami langsung maupun secara tidak langsung. Widja

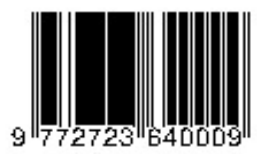


(1989:91) berpendapat sejarah adalah studi keilmuan tentang segala sesuatu yang telah dialami manusia di waktu lampau dan yang telah meninggalkan jejak-jejaknya di waktu sekarang. Pendapat tersebut menekankan perhatian diletakkan pada aspek peristiwanya sendiri, dalam hal ini terutama yang bersifat khusus dari segi urutan perkembangan yang kemudian disusun dalam suatu cerita sejarah. Pembelajaran sejarah berarti mempelajari peristiwa masa lalu untuk dijadikan pengalaman guna memperoleh kehidupan yang lebih baik di masa yang akan datang. Pembelajaran kooperatif, yang menjadi tema bahasan pembelajaran pada artikel ini, adalah pembelajaran dimana siswa bekerja sama dalam kelompok kecil dengan kemampuan yang berbeda dan saling membantu dalam belajar (Huda, 2015:32). Pembelajaran TGT merupakan salah satu model pembelajaran kooperatif yang menggunakan turnamen akademik, kuis-kuis, serta sistem skor kemajuan individu atau perwakilan kelompok (Slavin, 2010: 163-165).

Barcode atau QR Code adalah sebuah kode matrik dalam bentuk dua dimensi yang dikembangkan oleh perusahaan Jepang Denso-Wave pada tahun 1994 (Fauziah \& Djazari, 2018: 99-112). Dewasa ini QR Code banyak digunakan di beberapa institusi meskipun terus berkembang seperti Hongkong Institute Education, Bath University dan juga dipergunakan secara personal ataupun secara administratif (Nurming, 2008:255). Menurut Nurming, penggunaan QR code dapat meningkatkan motivasi dan menarik mahasiswa dalam pembelajaran bahasa asing. Susono dan Shimomura (2006) berpendapat tentang potensi besar QR Code dalam penerapannya di kelas bahkan sampai level penilaian, dari pendapat ahli ini sangat memungkinkan untuk dikembangkan menjadi media pembelajaran khususnya mata pelajaran sejarah. Hasil penelitian Guntur Firmansyah dan Didik Harianto (2019) menunjukkan bahwa QR Code layak dan dapat digunakan serta dapat meningkatkan motivasi belajar dan keterampilan dasar bermain tenis meja mahasiswa. Ariska dan Jasman (2016) menyatakan bahwa QR Code di bidang pendidikan sudah banyak digunakan untuk melabeli aset sekolah. Menurut Rochman, Rahajana, dan Taufik (2017), QR Code digunakan untuk menentukan validitas dan kartu rencana studi dan kartu hasil studi. Menurut Nurseto (2011) bahwa media pembelajaran sebagai media penyalur pesan dan informasi belajar yang dirancang secara baik akan membantu pencapaian tujuan pendidikan, sedangkan menurut hasil penelitian Halidi (2015) bahwa media pembelajaran berpengaruh pada motivasi belajar dan hasil belajar. Narayana (2009) berpendapat bahwa QR Code memberikan banyak solusi dalam sikap yang ingin dikaji. Pendapat ini memungkinkan untuk diadakan berbagai ujicoba atau eksperimen seperti praktik baik di sekolah.

Hasil belajar adalah hasil dari suatu interaksi tindak belajar dan tindak mengajar

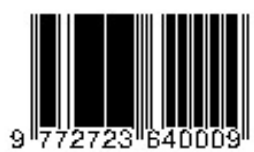


(Arifin, 2013:298). Dari definisi ini dapat dipahami bahwa guru setelah melakukan pembelajaran akan mengakhiri dengan penilaian hasil belajar, sedang siswa melaksanakan kegiatan puncak yaitu mengikuti evaluasi pembelajaran. Sedangkan menurut Sudjana (2016) hasil belajar adalah kemampuan yang dimiliki siswa setelah menerima pengalaman belajar.

Team Game Tournament (TGT) adalah model pembelajaran kooperatif yang menempatkan siswa dalam kelompok yang memiiki kemampuan, jenis kelamin dan suku atau ras yang berbeda (Isjoni, 2013:83-85). Guru memberikan tugas ke setiap kelompok untuk menyelesaikan permasalahan. Setiap anggota berperan menyelesaikan tugas kelompok, setelah penugasan selesai seluruh siswa/kelompok diberikan permainan. Menurut Kurniari (2006), model pembelajaran TGT merupakan model pembelajaran kooperatif dengan membentuk kelompok-kelompok kecil dalam kelas yang terdiri atas 3-5 siswa yang heterogen, baik dalam hal akademik, jenis kelamin, ras, maupun etnis. Inti dari model ini adalah adanya game dan turnamen akademik. Sebelum memulai game dan turnamen akademik, guru terlebih dahulu menempatkan siswa dalam sebuah tim yang mewakili heterogenitas kelas ditinjau dari jenis kelamin, ras, maupun etnis. Masing-masing siswa nantinya mewakili kelompoknya untuk bersaing dalam meja turnamen. Setelah kelas dibagi menjadi beberapa kelompok kecil, guru kemudian menyajikan materi dan membagi sub KD pada KD 3.3, selanjutnya siswa bekerja menyusun soal kuis dalam kelompoknya masing-masing.

Penyajian materi dalam TGT diperkenalkan melalui presentasi kelas. Presentasi kelas dilaksanakan oleh guru pada saat awal pembelajaran. Guru menyampaikan materi kepada siswa terlebih dahulu yang biasanya dilakukan dengan pengajaran langsung melalui ceramah. Selain menyajikan materi, pada tahap ini guru juga menyampaikan tujuan, tugas, atau kegiatan yang harus dilakukan siswa, serta memberikan motivasi. Setelah penyajian materi oleh guru, kemudian siswa berkumpul berdasarkan kelompok yang sudah dibagi guru. Setiap tim atau kelompok terdiri dari 3 sampai 5 siswa yang anggotanya heterogen. Belajar dalam kelompok sangat bermanfaat, karena dapat mengembangkan keterampilan sosial siswa. Keterampilan sosial memupuk keterampilan kerja sama siswa. Keterampilan sosial yang dimaksud adalah berbagi tugas dengan anggota kelompoknya, saling bekerja sama, aktif bertanya, menjelaskan dan mengemukakan ide, menanggapi jawaban/pertanyaan dari teman, dan sebagainya.

Apabila siswa telah selesai mengerjakan Lembar Kerja bersama anggota kelompoknya, tugas siswa selanjutnya adalah melakukan game. Game dimainkan oleh perwakilan dari tiaptiap kelompok pada meja yang telah dipersiapkan. Siswa yang tidak bermain juga berkewajiban mengerjakan soal-soal game beserta teman sekelompoknya dengan cara memindai barcode

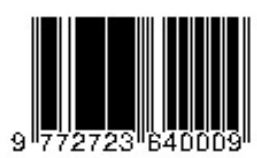


Subadi

Penggunaan Model TGT dengan Media Barcode Scanner untuk Meningkatkan Motivasi Siswa

yang ditayangkan oleh kelompok penanya.

Turnamen dalam hal ini dimodifikasi menjadi seluruh anggota kelompok terlibat untuk memberikan masukan jawaban ke tim. Sebelum jawaban atas pertanyaan disampaikan oleh perwakilan atau juru bicara kelompok, seluruh anggota kelompok terlibat untuk membaca barcode dengan cara menscan barcode dan mencari jawabannya.

\section{METODE PENULISAN PRAKTIK BAIK}

Kegiatan ini dilaksanakan di SMA Negeri 1 Matauli Pandan Kabupaten Tapanuli Tengah Provinsi Sumatera Utara yang beralamat di jalan Ki Hajar Dewantara No. 1. Pengambilan data dan observasi dilakukan selama proses kegiatan belajar berlangsung serta pemberian angket dilakukan pada saat kegiatan belajar mengajar telah berakhir.

Pengumpulan data dilakukan dengan melalui studi dokumentasi berupa hasil tes, silabus, RPP, daftar presensi, foto kegiatan KBM. Hasil tes meliputi nilai-nilai siswa setelah KBM belangsung sebelum menggunakan media Barcode Scanner dan tes setelah KBM menggunakan media Barcode Scanner. Data dukung lainnya yang digunakan adalah catatan perkembangan siswa di kelas selama berlangsung KBM dan hasil pengisian instrumen angket motivasi dan minat belajar. Menurut Sanjaya (2013:44), proses pengkajian masalah pembelajaran di kelas melalui refleksi diri dalam upaya pemecahan masalah dengan berbagai tindakan yang terencana dalam situasi nyata serta menganalisis setiap pengaruh dari perlakuan.

Subyek dalam pembelajaran dengan media barcode scanner ini adalah siswa kelas XII IPA 10 tahun pelajaran 2017/2018 yang berjumlah 24 siswa. Sumber data menurut Arikunto (2013:107) adalah subjek dari mana data penelitian diperoleh. Sumber data adalah hasil observasi terhadap siswa kelas XII IPA 10 SMAN 1 Matauli Pandan yang dilaksanakan pada semester I tahun pelajaran 2017/2018 saat berlangsungnya proses KBM di kelas tersebut di mana dalam proses pembelajaran tersebut guru mengimplementasikan model cooperative learning model TGT. Namun sebelum menggunakan media barcode scanner guru telah melakukan pembelajaran pada Kompetensi Dasar (KD) yang sama dengan metode ceramah dan tanya jawab, dan melakukan post tes atau penilaian. Sedangkan obyek dalam penulisan ini adalah media Barcode Scanner.

Instrumen observasi adalah alat yang digunakan untuk mengumpulkan data dalam suatu penelitian baik alat utama penelitian maupun alat pendukung. Alat utama yang digunakan adalah berupa angket motivasi dan minat, lembar observasi implementasi metode pembelajaran dan lembar observasi aktivitas siswa dan hasil tes. Data hasil tes yang telah terkumpul selanjutnya diolah dengan menggunakan rumus persentase untuk melihat nilai rata-rata dan

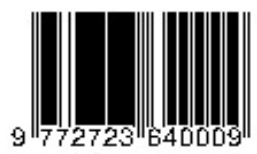


persentase ketuntasan belajar siswa secara individu dan klasikal yang dapat menggambarkan keberhasilan pembelajaran yang dilakukan. Siswa harus mencapai nilai minimal 75 agar dinyatakan tuntas dalam pembelajarannya. Persentase yang telah didapatkan kemudian dibahas atau didiskusikan dengan konsep yang sederhana.

\section{HASIL PEMBAHASAN DAN PEMECAHAN MASALAH}

Dalam tahap persiapan guru menyampaikan ke seluruh siswa di kelas XII IPA 10 untuk membawa HPnya dan digunakan bersama dalam pembelajaran sejarah. Dengan informasi ini siswa menyambut antusias, karena beberapa mata pelajaran tidak memperbolehkan melihat HP pada saat KBM. Dengan informasi disampaikan bahwa HP boleh digunakan pada saat KBM dan dijadikan media pembelajaran, dalam situasi ini siswa menunjukkan reaksi yang menggembirakan. Guru memberikan sekilas informasi bahwa akan digunakan aplikasi yang ada dalam HP untuk media belajar bersama.

Pembelajaran pada KD.3.3 dengan materi sistem dan struktur politik dan ekonomi masa demokrasi terpimpin, guru menggunakan model pembelajaran kooperatif TGT dengan media barcode scanner. Pengguna HP dapat dengan mudah mengakses informasi dengan dua langkah: 1) Scan $Q R$ Code atau Barcode, dan 2) Lakukan aksi-aksi, bisa berupa membuka browser, menyimpan informasi kontak, atau mendial nomor yang ada di barcode tersebut.

Guru memberi arahan kepada siswa untuk menghidupkan HP/android yang dipunyai kemudian mengunduh aplikasi $Q R$ Generator (QR Gen) atau $Q R$ Code Reader melalui playstore. Setelah semua siswa men-download aplikasi $Q R$ Code Reader atau barcode scanner, guru memberikan contoh cara mempergunakan aplikasi tersebut. Dengan $Q R$ Gen atau $Q R$ Reader kita dapat mengubah tulisan, angka atau gambar serta dokumen menjadi barcode code. Selanjutnya untuk membaca barcode dengan menggunakan barcode scanner. Dengan mendownload QR Code Scanner and Generator maka aplikasi ini sudah dapat dipergunakan untuk membuat barcode code dan sekaligus fasilitas untuk memindai atau membaca dan menyimpan hasil memindai selanjutnya bisa dikirimkan ke media sosial seperti WA atau telegram atau disimpan dalam penyimpanan bentuk lain.

Model pembelajaran TGT merupakan model pembelajaran kooperatif dengan membentuk kelompok-kelompok kecil dalam kelas yang terdiri atas 3-5 siswa yang heterogen, baik dalam hal akademik, jenis kelamin, ras, maupun etnis. Inti dari model ini adalah adanya game dan turnamen akademik. Sebelum memulai game dan turnamen akademik, guru terlebih dahulu menempatkan siswa dalam sebuah tim yang mewakili heterogenitas kelas

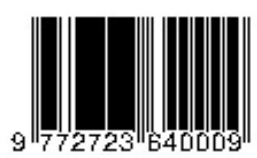


ditinjau dari jenis kelamin, ras, maupun etnis (Kurniasari, 2016). Setelah kelas dibagi menjadi beberapa kelompok kecil, guru kemudian menyajikan materi dan membagi sub KD pada KD 3.3 selanjutnya siswa bekerja menyusun soal kuis dalam kelompoknya masing-masing. Pembelajaran kooperatif dimana siswa bekerjasama dalam kelompok kecil dengan kemampuan yang berbeda dan saling membantu dalam belajar (Huda, 2015:32). Sedangkan menurut Slavin (2010:163-165), pembelajaran TGT merupakan salah satu model pembelajaran yang menggunakan turnamen akademik, kuis-kuis, serta sistem skor kemajuan individu atau perwakilan kelompok.

Tahap berikutnya yang dilakukan guru adalah membentuk kelompok dengan anggota 4 - 6 siswa. Setelah terbentuk kelompok, tiap kelompok diberikan tugas membuat soal kuis dan kunci jawaban singkat sebanyak 10 butir sesuai sub KD.3.3 yang sudah disepakati. Jika pembuatan soal kuis dan kunci jawaban sudah selesai maka tiap-tiap soal kuis dan kunci jawaban diubah dalam bentuk barcode dan diberi nomor 1 sampai 10 agar tidak salah, sehingga setiap kelompok memiliki 10 barcode soal kuis dan 10 barcode kunci jawaban kuis.

Tahap permainan memerlukan alat bantu yaitu: 1) seluruh siswa dalam kelompok wajib membawa HP-nya pada saat KBM; 2) LCD dan laptop dipersiapkan oleh guru; 3) semua soal kuis dan kunci jawaban sudah diubah dalam barcode dan disimpan di flash/ laptop; dan 4) papan skor. Bentuk permainan adalah sebagai berikut: Laptop yang sudah disediakan di meja depan disambungkan ke LCD untuk ditayangkan ke layar atau dinding. Kelompok 1 maju dengan membawa semua barcode yang telah disimpan untuk ditayangkan satu persatu sebagai pemberi soal kuis kepada kelompok 2. Sedang satu siswa perwakilan kelompok 3 menjadi petugas penulis skor di papan skor yang telah disediakan, untuk menuliskan skor yang diperoleh kelompok 2 yang akan menjawab kuis.

Seluruh anggota kelompok yang tidak bertanding juga harus menghidupkan HP-nya dengan barcode scannernya, sehingga siswa terlibat semua tanpa terkecuali. Pada saat kelompok satu menayangkan soal kuis yang pertama dalam bentuk barcode di layar, maka kelompok 2 seluruh anggotanya memindai barcode yang ditayang oleh kelompok 1 dengan cara menghadapkan perangkatnya yang telah diinstal aplikasi barcode scanner ke arah layar yang terpampang barcode. Demikian juga kelompok yang lainnya juga ikut memindai agar mengetahui soal kuis untuk bisa mengikuti materi sub KD yang ada, tetapi pada permainan pertama yang menjawab hanya kelompok 2 saja sampai soal ke 10 selesai.

Selanjutnya, petugas skor menjumlah skor yang diperoleh kelompok 2. Pada saat kelompok 1 memberikan waktu untuk memindai dan menjawab soal kuis jika benar seluruh

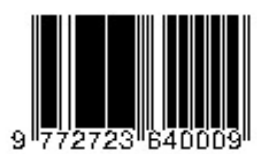


anggota kelompok yang ada memberikan tepuk tangan dan jika jawaban kelompok 2 salah, maka kelompok lain memberikan kata dukungan "Ayo kalian pasti bisa”. Penetapan skor tiap soal sudah disepakati bersama jika benar skor 10, jika setengah benar menurut kunci jawaban skor 5 dan jika salah skor 0. Begitulah permainan berlangsung sampai semua kelompok tampil seluruhnya. Untuk memberikan daya tarik ke semua kelompok di akhir seluruh permainan/turnamen guru akan memberikan hadiah kepada kelompok yang memperoleh skor tertinggi dan diakhiri foto bersama di kelas.

Pada kegiatan pembelajaran ini sangat terlihat antusias dan keterlibatan seluruh siswa dalam kegiatan pembelajaran. Kemudian guru memberikan angket (isian survey untuk dijawab siswa). Dalam pertemuan berikutnya diadakan evaluasi KD 3.3, adapun pengambilan survey dan hasil belajar dapat dijelaskan pada tabel 1 dan 2. Guru menganalisis semua data yang telah diperoleh berkaitan kondisi nyata di kelas selama berlangsung KBM dan pengamatan ketelibatan siswa seluruh kelompok, serta mencatat suasana psikologis dan ekspresi siswa ketika seluruhnya diperbolehkan menggunakan HP untuk kegiatan belajar yang selama ini penggunaan HP dibatasi ketika proses berlangsungnya kegiatan belajar mengajar. Persentase motivasi siswa untuk belajar sejarah kelas XII IPA 10 yang berjumlah 24 siswa setelah menggunakan media barcode scanner tampak pada tabel 1.

Tabel 1. Persentase motivasi siswa, data tahun 2017

\begin{tabular}{clr}
\hline No & \multicolumn{1}{c}{ Keterangan } & Jumlah \\
\hline 1 & Siswa merasa senang & 20 \\
2 & Siswa mengantuk & 0 \\
3 & Siswa menganggap sejarah mempengaruhi hidup & 13 \\
4 & Siswa tertantang belajar sejarah & 21 \\
5 & Siswa menganggap penting belajar sejarah & 10 \\
6 & Siswa yang tertarik sejarah & 21 \\
7 & Siswa yang ingin menjadi sejarawan & 0 \\
\hline
\end{tabular}

Berdasarkan data pada tabel 1, jumlah siswa yang mempunyai motivasi belajar sejarah dengan pembelajaran model TGT media barcode scanner adalah: siswa yang menyatakan senang berjumlah 20 siswa dari 24 atau $80 \%$, yang menyatakan tertantang karena ada permainan dan penggunaan android berjumlah 21 dari jumlah 24 siswa atau 87,5\%. Siswa yang mengantuk ketika pembelajaran dengan media android 0 atau seluruh siswa terlibat aktif dalam pembelajaran, sedang siswa yang berpendapat pelajaran sejarah berpengaruh terhadap hidupnya berjumlah 13 siswa atau 54\% (karena dikaitkan dengan penggunaan teknologi android yang sedang menjadi trend saat ini). Siswa yang menyatakan pelajaran sejarah penting

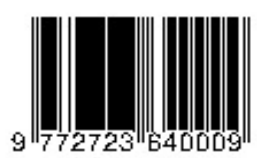


berjumlah 10 siswa atau $42 \%$, yang menyatakan pelajaran sejarah itu menarik berjumlah 21 siswa atau $88 \%$, sedangkan bila siswa ditanya apakah ingin menjadi sejarawan seluruh siswa tidak ada yang berkeinginan menjadi sejarawan.

Dari pembahasan praktik baik ini dapat dijelaskan bahwa masalah motivasi belajar meningkat dengan ditunjukkan jumlah siswa yang menyatakan senang belajar sejarah dengan menggunakan media barcode scanner. Peningkatan rasa senang siswa mencapai $80 \%$ atau sebanyak 20 siswa. Hasil pembahasan ini sejalan dengan pendapat Susono dan Shimomura (2006) tentang potensi besar $Q R$ Code dalam penerapannya di kelas bahkan sampai level penilaian. Hasil pembahasan praktik baik ini juga diperkuat dengan hasil penelitian Fajrin (2013) bahwa terdapat perbedaan motivasi peserta didik sebelum dan sesudah mempergunakan media pembelajaran berbasis teknologi informasi dan komunikasi (TIK). Demikian juga menurut pendapat Hamzah (2008), media video atau animasi yang ditayangkan dapat memunculkan motivasi. Diperkuat pendapat Howey (2008) bahwa pemberian skor dari jawaban kuis yang benar oleh kelompok/team dalam permainan merupakan strategi untuk memotivasi peserta didik. Heafner (2004) juga berpendapat bahwa pemanfaatan teknologi dalam PBM dapat meningkatkan motivasi belajar peserta didik, serta pendapat Susskind (2006) bahwa media pembelajaran berbasis TIK berpengaruh terhadap motivasi belajar peserta didik. Dengan kata lain, hasil belajar siswa setelah mempergunakan media pembelajaran barcode scanner mengalami peningkatan seiring dengan meningkatnya motivasi siswa. Hasil belajar siswa meningkat baik secara individual maupun klasikal mencapai ketuntasan belajar sesuai KKM yang telah ditentukan.

Tabel 2. Rekapitulasi hasil belajar dengan media barcode scanner, tahun 2017.

\begin{tabular}{clc}
\hline No & \multicolumn{1}{c}{ Keterangan } & Hasil \\
\hline 1 & Jumlah nilai maximal satu kelas & 2400 \\
2 & Jumlah nilai tercapai satu kelas & 2022 \\
3 & Rata-rata kelas & 84,25 \\
4 & Jumlah siswa yang tuntas & 22 \\
5 & Jumlah siswa yang tidak tuntas & 2 \\
6 & Persentase ketuntasan belajar & $92 \%$ \\
7 & Persentase ketidaktuntasan belajar & $8 \%$ \\
\hline
\end{tabular}

Pada tabel 2 memperlihatkan bahwa penggunaan pembelajaran model TGT dengan media Barcode Scanner diperoleh nilai rata-rata belajar siswa adalah 84,25 dengan ketuntasan belajar yang tercapai adalah 92\%. Dari persentase tersebut dapat dijelaskan bahwa terdapat 2 siswa dari 24 siswa belum tuntas belajarnya atau $8 \%$ siswa memperoleh nilai KKM Sejarah di bawah angka 75. Dengan demikian pembelajaran sejarah dengan model TGT menggunakan

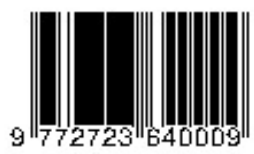


media barcode scanner mampu meningkatkan motivasi dan minat belajar siswa serta berhasil menuntaskan KKM sebesar 92\% atau 22 siswa. Kegiatan selanjutnya yang dilakukan guru adalah melakukan tindakan remedial 2 siswa yang masih di bawah KKM dengan memberikan penugasan individu agar bisa mendapat nilai sebesar KKM atau 75. Narayana (2009) berpendapat bahwa $Q R$ Code memberikan banyak solusi dalam sikap yang ingin dikaji. Pendapat tersebut sesuai dengan praktik baik yang dilaksanakan di SMAN 1 Matauli Pandan bahwa pembelajaran sejarah dengan menggunakan media barcode scanner dapat meningkatkan motivasi dan hasil belajar siswa bahkan dapat meningkatkan persentase ketuntasan belajar siswa baik secara individu maupun klasikal.

Aktivitas guru dalam persiapan penggunaan media barcode scanner adalah guru sebelumnya telah melaksanakan pembelajaran dengan metode konvesional dan telah melakukan evaluasi capaian untuk KD.3.3. Data yang diperoleh berkaitan dengan motivasi dan minat belajar siswa, serta hasil evaluasi belajar tersebut dapat dijelaskan sebagai berikut:

Tabel 3. Motivasi belajar sejarah konvensional, data tahun 2017

\begin{tabular}{clc}
\hline No & \multicolumn{1}{c}{ Keterangan } & Jumlah \\
\hline 1 & Siswa merasa senang & 2 \\
2 & Siswa mengantuk & 12 \\
3 & Siswa menganggap sejarah mempengaruhi hidup & 0 \\
4 & siswa tidak tertantang belajar sejarah & 20 \\
5 & siswa menganggap penting belajar sejarah & 2 \\
6 & siswa yang tertarik sejarah & 3 \\
7 & Siswa yang ingin menjadi sejarawan & 0 \\
\hline
\end{tabular}

Dari tabel 3 tersebut untuk jumlah siswa yang mempunyai motivasi belajar sejarah dengan model pembelajaran konvensional adalah: Siswa yang menyatakan senang berjumlah 2 siswa dari 24 atau 8\%, siswa menyatakan mengantuk berjumlah 12 dari jumlah 24 siswa atau 50\%, sedang siswa yang berpendapat pelajaran sejarah berpengaruh terhadap hidupnya (tidak ada), siswa yang menyatakan pelajaran sejarah itu penting berjumlah 2 siswa atau $8 \%$, siswa yang menyatakan pelajaran sejarah itu menarik berjumlah 3 siswa atau 13\% sedang siswa yang merasa tidak tertantang untuk berpikir belajar sejarah berjumlah 20 siswa atau $83 \%$ dan bila ditanya apakah ingin menjadi sejarawan, seluruh siswa tidak ada yang berkeinginan menjadi sejarawan.

Sesuai data pada tabel 3, bila diambil kondisi yang ekstrim yaitu siswa mengantuk 12 siswa atau setengah dari jumlah siswa di kelas, dan siswa cuek acuh karena merasa tidak ada tantangan dalam belajar sejarah sebanyak 20 siswa. Kondisi ini menjadikan pembelajaran

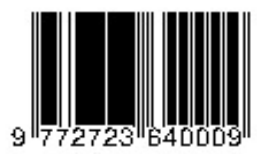


sejarah bagi siswa sifanya hanya untuk memenuhi kewajiban pelajaran yang harus diikuti selama di SMA peminatan MIPA. Hal ini menjadi tantangan bagi guru sejarah agar mencari solusi agar motivasi siswa meningkat dan tertarik belajar sejarah, serta memiliki pemahaman bahwa sejarah itu sangat penting untuk pembentukan watak bangsa. Di sisi lain, ada persepsi siswa yang mengganggap mata pelajaran sejarah tahun 2017/2018 tidak termasuk rumpun yang di-ujian nasional (UN)-kan, sehingga hal ini otomatis menjadikan pelajaran sejarah dinomorduakan dengan alasan persiapan ujian nasional. Kondisi yang mempengaruhi motivasi siswa cukup kompleks. Olleh karena itu, ketika sekarang semua mata pelajaran di-USBN-kan tentunya menjadi kesempatan bagi guru untuk melakukan inovasi merebut minat siswa untuk belajar sejarah.

Tabel 4. Rekapitulasi hasil belajar dengan pembelajaran konvensional, tahun 2017

\begin{tabular}{clc}
\hline NO & \multicolumn{1}{c}{ Keterangan } & Hasil \\
\hline 1 & Jumlah nilai maximal satu kelas & 2400 \\
2 & Jumlah nilai tercapai satu kelas & 1619 \\
3 & Rata-rata kelas & 67,46 \\
4 & Jumlah siswa yang tuntas & 9 \\
5 & Jumlah siswa yang tidak tuntas & 15 \\
6 & Persentase ketuntasan belajar & $37 \%$ \\
7 & Persentase ketidaktuntasan belajar & $63 \%$ \\
\hline
\end{tabular}

Data data tabel 4 dapat dijelaskan siswa yang memperoleh nilai 75 ke atas berjumlah $37 \%$ dari 24 siswa atau 9 siswa. Sedangkan siswa yang memperoleh nilai di bawah 75 berjumlah 63\% dari 24 siswa atau 15 siswa. Rata-rata nilai kelas 67,46 dengan KKM 75. Dengan data pada tabel 4, guru melakukan upaya mengubah model pembelajaran dan penggunaan media pembelajaran. Mengingat hampir seluruh siswa di SMA Negeri 1 Matauli Pandan memiliki HP, akhirnya guru memutuskan untuk menggunakan media perangkat HP sebagai media pembelajaran dengan aplikasi barcode scanner.

\section{KESIMPULAN DAN SARAN}

Simpulan dari praktik baik tentang penggunaan media barcode scanner dalam pembelajaran Sejarah adalah sebagai berikut: 1) Guru harus selalu mengadakan pengamatan dan melakukan perubahan model pembelajaran sesuai dengan karakteristik siswa dan kelas yang diajar; 2) Cooperative learning model TGT dengan media barcode scanner pada pembelajaran Sejarah di kelas XII IPA 10 SMA Negeri 1 Matauli Pandan dapat meningkatkan motivasi belajar siswa sebesar $80 \%$ serta menuntaskan pembelajaran 92\%; 3) Keberhasilan guru dalam menerapkan

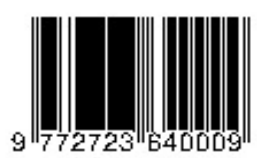


model pembelajaran TGT dengan media barcode scanner telah menstimulasi peserta didik untuk aktif terlibat, menampilkan karakter yang kreatif, efektif dan menciptakan suasana yang menyenangkan.

Berdasarkan simpulan tersebut dibuat saran. Bagi guru, sebelum melaksanakan pembelajaran kooperatif dengan pembelajaran model TGT dalam pendidikan sejarah harus mempersiapkan dengan matang. Salah satunya adalah guru mampu menentukan KD tertentu yang dapat diterapkan pembelajaran model TGT menggunakan media barcode scanner. Praktik baik berupa inovasi pembelajaran ini dapat dijadikan rujukan untuk penelitian tindakan kelas.

\section{DAFTAR RUJUKAN}

Arifin, Z. (2013). Evaluasi Pembelajaran. Bandung: PT Remaja Rosdakarya.

Arikunto, S. (2013). Prosedur Penelitian Suatu Pendekatan Praktis. Jakarta: PT. Rineka Cipta. Ariska, J. \& Jasman, M. (2006). Rancang Bangun Sistem Informasi Manajemen Aset Sekolah Menggunakan Teknik Labelling QR Code (Studi Kasus: MAN2 Model Pekanbaru). Journal Rekayasa dan Manajemen Sistem Informasi, 2(2), 127-136.

Fajrin, M. (2013). Pengaruh Media Pembelajaran Berbasis TIK terhadap Motivasi Belajar. Jurnal Penelitian UPI, 13 (2), 135-143.

Fauziah, D. \& Djazari, M. (2018). Pengembangan Media Pembelajaran QR Card Akuntansi Untuk Meningkatkan Motivasi Belajar Jurnal Penutup Siswa Kelas XII IPS SMA Negeri 2 Bantul Tahun Pelajaran 2018/2019. Jurnal Pendidikan Akuntansi Indonesia, 16(2), 99112.

Firmansyah, G. \& Harianto, D. (2019). Penggunaan QR Code pada Dunia Pendidikan : Penelitian Bahan Ajar. Jurnal SPORTIF: Jurnal Penelitian Pendidikan, 5(2), 265-278.

Halidi, H. M. (2005). Pengaruh Media Pembelajaran Berbasis TIK Terhadap Motivasi dan Hasil Belajar IPA Siswa Kelas V SDN Model Terpadu Madani Palu. Mitra Sains, 3(1), 53-59.

Hamzah, B. Uno. (2009). Teori Motivasi dan Pengukurannya (Cetakan ke-5). Jakarta: Bumi Aksara.

Heafner, T. (2004). Using Technology to Motivate Students to Learn Social Studies, Contemporary Issues in Technology and teacher, 4(1), 42-45.

Huda, M. (2015). Cooperative Learning: Metode, Teknik Struktur dan Model Penerapan. Yogyakarta: Pustaka Pelajar.

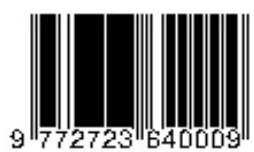


Howey, S.C. (2008). Factors in Student Motivations. Retrieved from the NACADA Clearinghouse of Academic Advising Resources.

Isjoni. (2013). Pembelajaran Kooperatif (Meningkatkan Kecerdasan Komunikasi Antar Peserta Didik). Yogyakarta: Pustaka Pelajar.

Joshua, E. S. (2006). Limits to Power Points Power: Enchancing Students Self Efficacy and Attitudes but not their Behavior. Computers \& Education, 50(4):1228-1239.

Kurniari, A. (2006). Komparasi Belajar antara siswa dengan metode Teams Games Tournament (TGT) dan Student Teams Achievement Division (STAD), Skripsi. UNS.

Narayana, A.S. (2012). QR Code and security solution. International Journal of Computer Science and Telecommunications, 3(7), 69-72.

Nurming dkk. (2018). Pemanfaatan QR-Code sebagai media pembelajaran Bahasa Asing pada Perguruan Tinggi di Indonesia. Prosiding Seminar Nasional Dies Natalis UNM Ke 57, pp. 253-260. ISSN 978-602-5554-35-3 (In Press).

Nurseto, T. (2011). Membuat Media Pembelajaran yang Menarik. Jurnal Ekonomi \& Pendidikan, 8(1), 19-35.

Rochman, F.F; Raharjana, 1. K \& Taufik, T. (2007). Implementation of QR Code and Digital Signature to Determine the Validity of KRS and KHS Documens. Scientific Journal of Informatics, 4(1), 8 .

Slavin, R. E. (2010). Cooperative Learning. Bandung: Nusa Media.

Sanjaya, W. (2013). Strategi Pembelajaran Berorientasi standar Proses Pendidikan. Jakarta: Kencana Prenada Media group.

Sudjana, N. (2004). Dasar-Dasar Proses Belajar Mengajar. Bandung: Sinar Baru Algensindo.

Susono, H. \& Shimomura, T. (2016). Using mobile phones and QR Code for formative class assessment, In current Development in Technology Assisted Education, Badajoz.

Widja, I. G. (1989). Dasar-Dasar Pengembangan Strategi serta Metode Pengajaran Sejarah. Jakarta: Depdikbud. 